\title{
Burkholderia mallei
}

National Cancer Institute

\section{Source}

National Cancer Institute. Burkholderia mallei. NCI Thesaurus. Code C86226.

A species of aerobic, Gram-negative, rod shaped bacteria assigned to the phylum

Proteobacteria. This species is nonmotile, encapsulated, catalase positive, oxidase and indole negative, and hydrolyzes starch. B mallei is found in contaminated soil, causes Glanders disease in horses, mules, donkeys, and humans, and has been developed and used as a biological weapon by the Germans, Russians and Japanese. 